\title{
Characteristics of EFL Curriculum in the Colombian Caribbean Coast: The Case of 12 State Schools
}

\author{
Yuddy Pérez ${ }^{1}$, Lourdes Rey ${ }^{1} \&$ Nayibe Rosado ${ }^{2}$ \\ ${ }^{1}$ Foreign Languages Department, Universidad del Norte, Barranquilla, Colombia \\ ${ }^{2}$ Spanish Department, Universidad del Norte, Barranquilla, Colombia \\ Correspondence: Yuddy Perez, Foreign Languages Department, Universidad del Norte, K. 5 Via Puerto \\ Colombia, Barranquilla, Colombia.
}

Received: August 28, 2019 Accepted: October 27, 2019 Online Published: October 29, 2019

doi: $10.5539 /$ elt.v12n11p85

URL: https://doi.org/10.5539/elt.v12n11p85

\begin{abstract}
Research related to English as Foreign Language (EFL) curricula in Colombia is scant and mainly focuses on the analysis of policies and the challenges they pose to institutions. Consequently, there is a need for studies of EFL curricula in place in Colombia to serve as basis for evaluation and adjustment of current educational policies. This descriptive study follows a qualitative exploratory approach and addresses this gap by identifying the characteristics of the EFL curricula from twelve state schools. Data were reviewed and evaluated using document and comparative analysis techniques. Results reveal that all institutions have curricular documents but not all those requested by the educational authorities. Some of these documents show a lack of consistency in terms of the conceptual underpinnings as well as a misalignment with the national requirements or with contextual needs. While awareness of the importance of having strong English programs and the positive outlook shown by institutional stakeholders seem to be conditions for success, limitations related to allocation of resources, classroom conditions, and environments conducive to learning hinder the implementation of the EFL curriculum.
\end{abstract}

Keywords: curricular documents, curricular characterization, state schools, EFL curriculum, language policies

\section{Introduction}

EFL curriculum enquiry has undergone significant development during the last decades, following epistemological shifts in the ways we understand learning, teaching and instruction (Schoenfeld, 2016). Authors such as Meyer (2006), and Sivesind, Afsar, and Bachmann (2016) suggest that these changes in curricula are also "products of globalization and the global society" or "responses to international demands sparked by the construction and use of standardized comparisons" (OECD \& Schleicher, 2012 cited in Sivesind et al., 2016, p. 347). Such demands force countries like Colombia to align their language policies and curricula to attract foreign investment (Peláez \& Usma, 2017; Usma, 2009, 2015) in an attempt to increase the country's competitiveness in the international arena.

In Colombia, curriculum enquiry is an incipient field (Aristizábal, 2008; Montoya, 2013). Research and publications related to the state of English as Foreign Language (EFL) curricula is scant in this context. Existing contributions target national policies for EFL teaching and learning from perspectives such as ideology analysis (Guerrero, 2008, 2010), challenges posed to institutions in rural areas (Bonilla \& Cruz-Arcila, 2014; Correa, Usma, \& Montoya, 2014; Usma, 2015), or posed to central actors traditionally neglected in the implementation of policies (Correa \& Usma, 2013; Fandiño, Bermudez \& Lugo, 2012).

There is an emerging body of literature focusing on EFL curricula in some regions of Colombia (Bastidas, 2017; Cárdenas \& Chaves, 2013; Cárdenas \& Hernández, 2012; Correa et al., 2014; Miranda \& Echeverry, 2010, 2011; Quintero \& Guerrero, 2013; Usma, 2015). This literature highlights the disconnection "between the policies and programs being formulated, and the reality being experienced by educational communities in the different regions of the country" as reported by Pelaez and Usma (2017, p. 122). However, most studies analyze how policies are or should be implemented in the regions and the challenges posed by policies, but do not describe EFL curriculum in terms of their current features. Therefore, investigating the status of EFL curricula in Colombia is significant as there are concerns among scholars and governmental bodies in relation to Colombians' English proficiency levels that place the EFL curriculum at the center of the discussion. As Confrey (2006) claims "this scrutiny is warranted 
because of the critical role of curricula in influencing what students learn and when and how well they learn it" (p. 195). Curricular analysis provides us with an opportunity to examine the values and elements that are presumably reflected by EFL curriculum writers. This will contribute to shape the future directions of EFL teaching and learning in our country and in contexts similar to ours from a data-informed perspective. Our guiding question is: what are the salient characteristics of curricula in place from twelve state schools in the Caribbean coast of Colombia and how do they reflect the demands of national policies? Before we turn to methods and results of this study, we must first look at the demands of EFL national policies and curriculum development in Colombia.

\subsection{EFL Policy and Curriculum Development in Colombia}

Historically, the Colombian Ministry of Education (MEN) has issued different initiatives to promote English language learning in the country. These are, in chronological order and, as reported by Usma (2009): the English Syllabus (1982), the COFE project (1991), the General Law of Education (1994) and the Curricular Guidelines for Foreign Languages (1999). However, EFL policy has become more vigorous in the last decade.

In 2005, a national English language policy was launched by the MEN and made official through the National Program for Bilingualism (PNB). This program was created to contribute to "the education of citizens capable of communicating in English, with internationally comparable standards" (MEN, 2006, p. 6) and involved a series of initiatives such as the National Standards for foreign language learning, the improvement of teachers' language proficiency and the updating of teaching practices, the testing of students' English skills, and the accreditation of English teaching institutions (Herazo, Jerez, \& Lorduy, 2012). One contribution of the program was the publication of the National Standards that have been used by educational institutions as their guide for EFL curriculum construction and design.

With the change of the government and the political party in power in 2010 in Colombia, and in light of the unsatisfactory results obtained by the PNB evidenced through the results in the national standardized test SABER 11, a new EFL educational program was established. It was named Foreign Language Competence Development Strengthening Project (2010- 2014). The aim of this revamped program was very similar to that of its predecessor but this time a legal support to the program was added through the passing of the Bilingualism Law (Congreso de Colombia, 2013). The new law established that English was the official foreign language to be included in the national EFL curriculum excluding other foreign or native languages. However, after five years of this second program, a third was established: Colombia Very Well! (2015-2025). It only lasted 5 months as it was replaced by Colombia Bilingüe (2014-2018) with a change of government. This continuous transformation shows that the results obtained were not as expected and that the policy required adjustments.

In sum, Colombian language policies, in essence, seem to reflect the processes of internationalization and neoliberal globalization. They focus in the economic need of preparing an English speaking workforce (Reyes, 2015) sidelining the important goal of preparing Colombians for the demands of communication and peace building in a post-conflict era (Birch, 2009). The policies and the programs derived from them included innovations such as language and methodology education programs for in-service teachers; the evaluation of students' language skills through massive application of standardized tests; the design and release of textbooks (English, please!) and the presence of international volunteers in charge of co-teaching English with local teachers as a way to strengthen students and teachers' language development (Bonilla \& Tejada, 2016). However, none of these innovations addressed the EFL curriculum as a decisive factor in the educational process.

The first document that defined the need for the design of a national English EFL curriculum was the 2014-2018 National Development Plan (Colombia, 2014). For the first time in ten years since the policy implementation, the EFL curriculum was acknowledged as a key element of the English teaching and learning process. To comply with this action, a Suggested EFL curriculum for the $6^{\text {th }}$ to $11^{\text {th }} 1$ grades of the Colombian Educational System was released. Launched in 2016, it aims to help institutions strengthen their existing EFL curriculum or adopt and adapt the proposed document depending on their needs (MEN, 2016). The curricular document includes a detailed syllabus by grade, a scope and sequence chart, some pedagogical and assessment recommendations; and guidelines for teachers, Local Education Authorities (LEAs) and parents. It also contains a set of Basic Learning Rights (BLR), which refer to the basic knowledge students are entitled to have. It has been defined as flexible and adaptable to make it useful for the different types of schools, teachers, students and communities in the country.

In a second phase, the EFL curriculum guidelines for elementary school ${ }^{2}$ were designed. Released in 2017, this document follows some of the principles of the Suggested EFL curriculum for $6^{\text {th }}-11^{\text {th }}$ adapted to the cognitive and developmental characteristics of primary students. It follows a task-based approach which aims to adapt to different communicative situations to enhance meaningful learning for children. It also includes a detailed syllabus per grade, a scope and sequence chart, pedagogical and assessment recommendations for teachers, guidelines for 
parents and LEAs, an implementation guide and the BLRs.

These curricular initiatives are in the process of integration and implementation in Colombian educational institutions, and their impact is still to be studied and reported by the academic community. The contribution of this study is therefore pivotal since it describes the state-of-the-art before the release of the Suggested EFL curriculum for this particular context. As mentioned, studies about this issue are scant in the country.

\subsection{EFL Curriculum}

The term curriculum derives from the latin word currere, which refers to a career, a journey that needs to be made (Gimeno, 2005, p. 144). The Collins dictionary defines it as "the different courses of study that are taught in a school, college, or university" (2018). In Colombia, as in other countries, the EFL curriculum is also "a living element, the outcome of forgotten struggles and difficulties and of battles of long ago" (Wolhuter, Van der Walt, Potgieter, \& Steyn, 2014) reflecting the secret workings of national life. The EFL curriculum, as the life of the country, changes on the one hand as a response to the internal demands of the society, and on the other hand, to the pressures of internationalization and globalization. The ultimate goal of EFL curriculum change should be improving the quality of education in our country and in Latin America. However, this goal has not been achieved.

According to Lago, Aristizabal, Navas and Agudelo (2014), the curricular discussion in Colombian started in the middle of the 20th century. The initial curricular influence from the 60 's, 70 's, and 80 's originates from North American models supported in concepts such as development and planning which are reflected in the objective-driven curricula that flourished during those decades. In the 90's, there was a great milestone in EFL curriculum transformation in the country triggered by the constitutional reform in 1991 from which the General Law of Education (1994) and the Law of Higher Education (1992) derived.

The Law 115 from the General Law of Education in 1994 addresses all aspects of the curriculum and plan of studies and defines it as:

The whole of the criteria, plans of study, programs, methodologies, and processes that contribute to the integral formation and construction of cultural identity at the national, regional, and local level, including human, academic, and physical resources, in order to put policies into practice and carry out the "Institutional Educational Project (PEI)" (MEN, 1994, Article 76).

In 2016, the MEN stated that it was "necessary to define the concept of EFL curriculum, a term that has had many interpretations" (p. 19) due to its complex nature and inherent multilayered relationships (Osorio, 2017).The Ministry used Bertalanffy's (1968) and Morin's (2004) ideas to propose its definition of EFL curriculum as "a whole", a system with components that are interrelated with the greater context in which it is simultaneously and openly implemented (Colombia, 2016, p. 19). They considered parts or components of the EFL curriculum: everything that allows its movement or dynamism and which traditionally responds to the following questions:

1) What should be included in the English teaching-learning process?

2) When should teaching-learning be approached?

3) How should teaching-learning be approached?

4) What, how and when should learning be evaluated? (2016, p. 20).

They also proposed that such components should be arranged as "a curricular framework having macro, meso and micro relations" (2016, p. 20) and which may include the following elements (Colombia, 2016, p. 13):

Scope and sequence chart: describes the EFL curriculum as a matrix of objectives assigned to the grades (sequence) and grouped according to a common theme (scope).

Programs of study: presents a plan that usually includes fundamentals, themes, resources and evaluation.

Content scheme: indicates a list of topics to cover and that are arranged as a scheme.

EFL National Standards: a list of knowledge and abilities required by all students to complete their academic process, as those defined in Guide 22.

Textbooks: educational materials used as teaching guides in the classrooms.

Learning path: courses and levels that comprise the program and that the students must complete.

Planned experiences: all academic, athletic, emotional or social experiences that the students experience and that have been planned by the school.

Historically in Colombia, there has not been a unified EFL curriculum; rather, the government has encouraged autonomy in schools by providing supporting documents that could be used to guide a contextualized EFL 
curriculum design process (Curricular guidelines, Standards, Suggested EFL curriculum for Primary and Secondary school). However, there is very little knowledge and research about how the curricula designed by institutions responds to official guidelines and to theoretical curricular principles (Cardenas, 2006; Sanchez \& Obando, 2008).

\section{Method}

This is a qualitative descriptive study (Creswell, 2003). This type of research studies a phenomenon and its features in its "natural settings without any intervention or manipulation of variables" (Nassaji, 2015, p. 129). The phenomenon was the EFL curriculum in place in state schools in Colombia.

\subsection{Context and Participants}

The twelve state schools whose curricula are analyzed participated in an academic innovation program set up by the LEAs (Barranquilla and Cartagena) to respond to the National Bilingual Program demands. This program ran from 2011 to 2015 with the support of a local university and it was developed in stages (diagnosis, planning, intervention and evaluation) in which university researchers collaborated with teams in each school to revamp the English language program.

The diagnostic stage helped to identify the status of the English program in the school in terms of EFL teachers' language level, the use of the national EFL standards in the EFL curriculum, the commitment of the institution towards English teaching and learning, and, students' results in the English section of the national standardized test (SABER 11) at the end of their high school cycle. The planning stage aimed to organize a team of teachers and administrators to plan and lead the curricular activities and processes (the intervention) for the betterment of the English language program. The intervention stage focused, on teacher development on the one hand, which aimed at strengthening English teachers' pedagogical practices as well as language skills; and on the actual implementation of the planned curricular revamping actions on the other. The fourth stage allowed stakeholders to keep track of the implementation of agreed actions and to gather information about the strengths and areas to improve after the curricular revamping had been implemented.

The twelve institutions were chosen by the corresponding LEAs based on their willingness to strengthen their English programs as well as the ongoing actions taking place at the moment of the intervention. Five normal schools $^{3}$ and seven regular schools were selected.

\subsection{Data Collection and Analysis}

This study is based on the information obtained from the diagnostic reports from the twelve institutions participating in the program. Researchers only had access to stakeholders' data using the information presented in the above-mentioned reports. These reports contained descriptive information about each institution's curricular documents which include Institutional Educational Project (PEI), the English program and its syllabi (if present), and assessment policies. The diagnosis reports also contained an analysis of the schools' scores from the SABER 11 tests from the previous three years, as well as qualitative information about perceptions obtained from semi-structured interviews with school administrators, focus groups with students and teachers, and surveys completed by parents. Document analysis (Bowen, 2009; Sarmiento, Empresas, \& Tovar, 2007) was used as a systematic procedure for reviewing and evaluating all the data from the diagnostic reports produced at the initial stage of the program.

The information about curricular documents found in the diagnostic reports was analyzed using a checklist to look for patterns in terms of existence, pertinence, and coherence. These criteria were chosen since they represent some of the basic features or qualities that the EFL curriculum should include (Stabback, 2016). Existence (E), as the name suggests, refers to the presence of the expected curricular documents in each institution; pertinence (P) relates to the relevance of the document to the needs of the institutional and local contexts (UNESCO, 1998; Malagon-Plata, 2009); and coherence (C) refers to the consistency of concepts used throughout the documents (Ruiz, Montenegro, \& Meneses, 2010). One (1) was assigned when the category was present, and zero (0) when it was not. Percentages were assigned in relation to the total number of documents expected $(n=60)$. These 60 documents result from a multiplication of the five expected documents (e.g. Institutional Education Project, the English program, the scope and sequence chart, the syllabi, and the assessment policies) by twelve institutions.

Then, a comparative analysis of the national standardized test scores (SABER 11) from the previous three years was run to have baseline data on students' general competence in English when they finish high school in each institution. Results were organized into the corresponding levels of the Common European Framework (CEFR) (Council of Europe, 2001) to compare results between cohorts within the same institution and compare the global school performance with the national goal for high-school (pre-intermediate or B1 level. 
The data from interviews, focus groups, and surveys added students, teachers, parents and school administrators' views of the role of English in their respective institutions. This information was analyzed by researchers whose detailed reading allowed for the identification of the following categories: perceptions regarding the impact of the English program, its effectiveness, and the motivation for the program in addition to students' academic performance. These resulting categories helped to characterize the EFL curriculum in the institutions as well.

\section{Results}

\subsection{Curricular Documents}

The analysis carried out in the diagnostic reports looked at the existence, pertinence, and coherence of curricular documents. In terms of existence, the analysis revealed evidence of 30 documents out of the 60 expected documents. These represented $50 \%$ of the expected curricular documents in the institutions. The reports also showed that in five of the twelve institutions, the PEIs made explicit reference to initiatives for strengthening the English program in these schools. Furthermore, all institutions showed consistent use of the EFL National Standards as the institutional English program and as a basis for the scope and sequence chart found in institutions. Reports also revealed that grade-by-grade syllabi were incomplete, outdated or misaligned with no mention to pedagogical guidelines or content schemes found in the documents. In terms of assessment documents, we only found three documents that described explicit strategies and tools to evaluate students' learning (5\%).

As regards pertinence, $15(25 \%)$ of the curricular documents analyzed were considered relevant to the particular context and needs. For instance, the analysis showed that three scope and sequence charts responded to the characteristics and needs of their contexts as declared in the PEI of the institutions. Also, eight English programs were considered pertinent because the stated language expectations matched the institutions' stated profile. Five of those English programs showed an understanding of the role of English in supporting students' holistic language development in their particular contexts. The lowest percentage of pertinence was found in the English assessment guidelines (1.6\%). Only one of the three assessment documents found related to the learning outcomes stated in the English programs.

Out of the three criteria, coherence obtained the lowest percentage (3\%) meaning that only two documents were considered coherent after the analysis. One PEI established a coherent relation between the school's stated approaches to teaching and learning and the guidelines established by the MEN. A second PEI showed a consistent use of appropriate conceptual foundations throughout its English program in terms of pedagogical strategies and skills development.

\subsection{Standardized Test Results}

The three-year-score comparison showed that the majority of the students in the institutions placed below the national expected level (pre-intermediate or B1) In fact, $58 \%$ of said students demonstrated a level below A1, 17\% showed level A1 or A2 while $25 \%$ reached a B1 level in 11th grade.

Similarly, when analyzing and comparing cohorts within each institution, we found that in $33 \%$ of the institutions results dropped from A1 to -A and in 9\% of the institutions results remained -A for three years. By contrast, $34 \%$ of schools showed a slight tendency to move either from -A to A1 (25\%) or from A2 to B1 $(9 \%)$ year after year; and in 33\% of the institutions, results fluctuated between A2 and B1 during the three year period.

\subsection{Interviews, Focus Groups and Surveys}

These data were categorized into four main themes: perception regarding the impact of the English program; program effectiveness; motivation; and students' academic performance.

As regards perception, actors from the twelve institutions reported that the program has had a positive impact in their institution as evidenced in the institutional billboards, in blogs, on webpages, and in the development of cultural activities throughout the academic year. This was also seen in the reported awareness of the school community in terms of their willingness to work on the improvement of the English language teaching and learning program in their respective institutions.

All actors from the school community perceived learning English as beneficial for students. They highly valued the opportunities provided by the LEAs and the MEN to participate in different development initiatives such as the English without Borders Program and the Institutional English Strengthening Program (IESP). They also appreciated the elaboration of national documents such as the English Language Standards, the design of materials available for all institutions (e.g. English for Colombia and Bunny Bonita), and the presence of international volunteers at their schools.

Another aspect is the shared perception of the quality of their human resources (teachers, administrators and 
international volunteers). According to the different stakeholders, teachers were always open and valued suggestions for improvement. Besides, the administrators had a positive attitude that supported the success of the implementation of the English language program and were always willing to help teachers. Likewise, the contribution of international volunteers in class activities and in the creation of an intercultural learning environment was perceived as key in the learning process. Furthermore, students also enjoyed their presence and saw it as an opportunity to learn about other countries and cultures. In sum, in the reports, stakeholders reported commitment to the success of the program and considered it had a positive impact on the institutions.

Regarding the effectiveness of the English program, there was a positive outlook about the program and the identification of factors affecting its implementation. The participants highlighted teachers' ineffective pedagogical practices, lack of materials and resources, the high number of students per class and the insufficient hours of instruction as factors affecting the implementation of the English program in their respective institutions. Students considered that there should be better and more demanding teaching-learning processes as they recognized that learning objectives are not being attained and wanted their teachers to prepare better lessons. Teachers also reported the need to meet regularly with their colleagues to discuss aspects related to the English language learning process and to report to school administrators as well as the necessity that those times be planned and built into their schedules. They complained about how participation in numerous school projects affected the actual time they devote to the English language project. One issue recurrently identified by stakeholders was the misalignment of government regulations and schools needs to have professional English teachers at primary level.

In terms of motivation, primary students in seven institutions (58\%) reported that they found classes motivating because of their involvement in activities such as singing, drawing, and playing, which they considered fun. High school students in five schools (41\%) recognized the importance of English for their future professional life, especially those from the normal schools who would soon become primary teachers. Parents in nine institutions (75\%) acknowledged the motivation reported by students. English teachers in eleven institutions (92\%) acknowledged feeling self-motivated to teach at their institutions and motivated their students in their English classes. Subject teachers in ten institutions (83\%) stated that they have witnessed how the strategies implemented so far in their institutions to strengthen the English program have had a positive impact on students' motivation and interest to learn the language.

With respect to students' academic performance, in six institutions (50\%), students reported having a better performance in activities related to vocabulary and grammar and an improvement in their communicative abilities as a result of the program in place at the moment of the study, but they also considered their level of achievement was still low when compared to other subjects in their curriculum. This perception was corroborated by English teachers and administrators who recognized that students' language abilities still required further development and improvement. They also reported a high percentage of students failing the English courses.

\section{Discussion}

This study aimed to characterize the EFL curricula in place in 12 state schools in the Northern Coast of Colombia and identify their features in relation to the demands of national policies. The discussion will present the analysis of the findings in terms of strengths, weaknesses, opportunities and threats to summarize previous analysis and facilitate interpretation.

\subsection{Strengths}

Strengths reported touched on various aspects related to the English curriculum in these institutions. First, all institutions have available curricular documents. The English program, which is understood as the syllabi per grade, as well as the scope and sequence chart were found in almost all institutions. In addition, the use of the National English language Standards was also consistent in all institutional documents found. This may imply that institutions and teachers have a clear interest in complying with the policy and set to use these government documents as a basis to construct the required curricular documents and to guide their practice.

Second, human resources were highly valued. Teachers and international volunteers were acknowledged for their contribution to the English learning process and for their effort in improving their teaching practice while administrators were recognized for their commitment to support the English language program and its implementation. The active participation of all the stakeholders in the initial stage of this project was clear evidence of that interest. This may indicate a supportive atmosphere towards the English language learning project, and although it did not show how these actors contribute directly to the curriculum, it could be assumed that this task would be tackled positively. This positive atmosphere was also evident through the advertising schools did for the English project through billboards, webpages and events. 
This finding above is in line with what Miranda and Echeverry (2011) considered a prerequisite for the successful implementation of English programs and innovations: stakeholders' commitment to the project. This commitment was present in all of the participant institutions. Even if teachers had to work harder and meet with the advisors, they took this responsibility very seriously. These findings were positive as some other studies reported that poor awareness within school communities about the importance of English in the institutions (Bastidas \& Muñoz, 2011) affected the attainment of the expected objectives. Fandiño, Bermudez and Lugo (2012) explained that the absence of a shared understanding of the rationale of such programs, and how and when to implement them in their respective contexts impacts their success. From all of the above, there appear grounds for optimism that the participants' institutions in this study can embark on successful English language curriculum renewal processes.

Student motivation is another positive aspect identified. In primary, students report enjoying their English classes because they considered them as fun. Besides, to a minor degree, high school students realize the importance that the English language holds for the university and their professional future. This coincides with Marulanda and Berdugo's (2011) findings. They found that sixth graders showed more motivation than students in higher grades, and this motivation was associated to the development of ludic activities. However, such activities are not enough to sustain language development; they also have to be effective, meaningful and increasingly demanding to help students advance in their competence. According to Bastidas and Muñoz (2011), commitment alone is not enough and other factors, such as having a coherent and well-structured curriculum, should be addressed for the process to be successful.

In sum, schools have conditions such as stakeholders' interest and support as well as students' motivation to develop English language curricula. These conditions are key to support students learning and facilitate the attainment of the pre-intermediate English level (B1) established by the MEN.

\subsection{Weaknesses}

The first weakness found is a misunderstanding of what a curriculum should entail. Most of the institutions do not have all the curricular documents expected by the MEN (2016) and LEAs. Some of them were missing; others were incomplete, misaligned, or lacking coherence and pertinence. In many of the schools, syllabi were outdated and incomplete lacking specific actions to guide the scope and sequence documents. Pedagogical guidelines and content schemes were lacking and the existence of assessment documents in participating schools was minimal. Other studies have shown similar results (Bailey, Rosado, \& Rey, 2018; Bastidas \& Muñoz, 2011; Marulanda \& Berdugo, 2011) in which schools did not have the description of the English program or the syllabi affecting the progression in teaching from grade to grade.

The lack of basic curricular documents affects English teaching and learning processes as without these documents, teachers find it difficult to establish a clear progression of the process, and students have no clear goals to achieve grade by grade. In other words, there is no clear pathway to follow and therefore no way of assuring that the expected outcomes will be attained. The design of complete, aligned, coherent and pertinent curricular documents seems to be an urgent task (Velazco, 2011). This task should be planned and supported by school administrations and developed by the academic community provided there is time and expert guidance to guarantee quality and an effective response to schools' needs.

These findings may relate to the results of the SABER 11 test that show that students seem not to be advancing in their English language learning and that, in spite of several years of language education, there is no significant progress in their learning process, even after the implementation of national policy. Similar results have been reported by Lopez et al. (2009, 2011) and Bonilla and Cruz-Arcila (2014). English language learning and teaching require some solid grounds that should be stated in curricular documents and interpreted by teachers in instruction and assessment to guide students to effective learning.

Another finding is the effect of unfavorable conditions existing in the institutions to support the English language programs. Some of those conditions included the excessive number of students per class, the insufficient time allotted for English language instruction, as well as inadequate resources and equipment reported by students, teachers and parents. This finding has been discussed in studies conducted in Colombia (Bastidas, 2017; Bastidas \& Muñoz, 2011; Bonilla \& Cruz-Arcila, 2014; Cárdenas \& Chaves, 2013; Cárdenas \& Hernández, 2012; Correa et al., 2014; Lopez et al., 2009; Miranda \& Echeverry, 2010, 2011; Quintero \& Guerrero, 2013; Usma, 2015). Unfavorable conditions may result in poor instruction and development because even schools with well-structured curricula would fail to help students' language development if conditions are not optimal for learning.

\subsection{Opportunities}

Opportunities to improve the process were also identified by the different stakeholders. As found in the data, all of 
the actors value the initiatives the government offices offer to schools that sometimes represent allocation of resources. This seems to generate commitment among teachers, students and administrators to make things better and show improvement. Teachers reported these benefits in terms of opportunities for professional development through English language and pedagogy courses. They also expressed their gratitude for the access to materials that could be used freely in their classes as their students cannot, in many cases, afford to buy commercial textbooks. However, none of the participants reported the need for the government to invest resources in designing well established curricula. Now that the MEN has their Suggested Curricula and the Basic Learning Rights in place, these offices, especially the LEAs, could focus efforts and allocate resources in helping schools and teachers use these tools to improve their English language teaching and learning.

Some other opportunities should be related to taking advantage of the positive atmosphere in schools in order to develop innovations such as interdisciplinary projects. These innovations would enrich the EFL curriculum and make it meaningful for the school community.

\subsection{Threats}

The different stakeholders identified a variety of aspects that make the English learning process difficult, and these can be classified as administrative or academic threats.

In terms of administrative issues, the main threats were related to the absence of resources, rooms with poor conditions, a large number of students per class and the limited number of hours assigned to English classes. These conditions have to be addressed jointly by the MEN, the LEAs and the institutions as even the best articulated curriculum cannot guide an effective language learning process with insufficient number of class hours, an unmanageable number of students, poor infrastructure (lack of appropriate settings, books, audio-visual materials and equipment).

Teachers expressed that they would like to have time to meet with colleagues as faculty meetings are not scheduled by the administrators. Teachers would like to have the opportunity to discuss and share with peers aspects related to the curriculum and their practice in order to grow professionally. If schools do not provide these spaces, the curriculum will not be discussed, understood, reviewed and improved as a result of these meetings.

Another threat is that in Colombia, professional English teachers cannot be assigned to primary level. This affects the learning process as all the documents the MEN has designed include English language teaching from pre-school onwards, but the success of these initiatives will not be achieved if there are no English teachers in charge of the process. Although this threat goes beyond the scope of this study because it is a national regulation, teachers' voices should be heard and should help the MEN to make a coherent decision that supports its policies.

In terms of academic threats, the main finding is what was reported earlier about schools not having coherent and pertinent curricular documents as expected. This may reflect a lack of understanding regarding what the curriculum entails. This affects the teaching and learning as no logical alignment between curriculum, instruction and assessment can be achieved if one these elements is incomplete. This could be seen in what parents, students and administrators have reported in terms of teachers using decontextualized teaching methods and the use of Spanish as the only language for communication in the English class. Students also indicated that teachers tend to use repetitive activities that affected students' engagement and motivation. This situation seemed to generate discipline issues that affect the class development and hence the language learning process.

\section{Conclusion}

This study led us to conclude that while a national English language policy has been in place since 2005, EFL curriculum design and implementation has remained as a problematic issue at school level. Although the study showed that educational institutions use some curricular documents, in most cases these documents were not complete or those required by the educational authorities were not present. This situation may lead institutions, teachers and students to uninformed decisions of what is to be taught, how it is to be taught, and how it is to be assessed affecting the quality of English language learning. Therefore, it would be necessary for any educational institution to work towards an articulated curriculum that includes all the necessary elements to attain the expected outcomes.

One of the key features of strong curricula is the consistency of concepts throughout the documents. A lack of coherence is evidenced through the misarticulation of the theoretical and practical underpinnings stated in the documents in terms of the conceptualization of language, language learning and teaching, and assessment. This contributes to a widening of the gap between what is written in the documents and what is done in the classroom, resulting in a curriculum that fails to achieve the expected results in terms of supporting students' language learning and development. Apart from issues of existence and coherence, curricula should be pertinent to the 
context in which it is used. Pertinent curricula should take into account the reality of the institution and that of the students and teachers in order to make the established learning outcomes more attainable. The importance of these three elements (existence, coherence and pertinence) leads us to the understanding that their absence may hinder students' foreign language development. The only indicator so far is the score students obtain in the national standardized test. Further efforts to design institutional- based assessment, and research on how the curriculum can respond to local needs are required.

Institutions need to realize that curriculum design and implementation is a collective endeavor where all stakeholders should have a clear role. In the participating schools, these collaborative efforts were absent and not considered in the institutional strategic plans in spite of the positive attitude towards the program. Collective participation may guarantee higher levels of existence, pertinence and coherence within the curriculum in place. Improving the existing curricula should include commitment and support from the institutions' communities, collaboration among English teachers, and allocation of necessary resources by the school administration. This curriculum design task should become a systematic activity within the institutional planning culture and authorities would need to assure favorable conditions for a successful implementation and evaluation.

Another aspect affecting curriculum design and implementation is related to the conditions in which this curriculum is implemented. Factors such as number of hours of instruction, number of students per class, access to materials, and quality of classroom settings are key to support the adequate delivery of the curriculum and to create supportive learning environments. Even schools with strong curricular documents will fail in the language learning process if appropriate conditions are not given.

In spite of these results, there were some positive aspects found in the data that could serve as a springboard for curriculum improvement and success in educational institutions. One of these is the awareness gained by schools' administrators and teachers of the importance of having a strong English program in order to meet established institutional and governmental goals, but most importantly students' development goals. If the institution understands this need, decisions about time release for teachers, provision of adequate conditions for the curriculum creation and delivery as well as a continuous follow up of the process will become part of the institutions' routines leading to success.

In sum, designing pertinent and coherent comprehensive curricular documents within appropriate conditions is a decisive and urgent process in educational institutions in Colombia. The benefits of the completion of this endeavor will generate more commitment of the institution community, leading to improvement of students' language learning processes and therefore raising the level of educational quality and human and economic development in the country.

This study made a contribution by establishing characteristics of EFL curricula in place in some state schools in Colombia. Despite the limitation in the number of participating schools and given the scarcity of information found in the context, this could be a starting point for more studies like this to be conducted in different institutions in the country or in other institutions around the world to share lessons learned in the area of current curriculum characteristics. More research in the field would allow us and other researchers in the field to compare data from various contexts and across geographical areas.

\section{References}

Aristizábal, M. (2008). Prólogo. In M. Aristizábal (Ed.), Traslapamiento de la pedagogía por el currículo: Colombia 1960-1975 (pp. 7-16). Popayán: Universidad del Cauca.

Bastidas, J. A. (2017). More than half a century teaching EFL in Colombia secondary schools: Tracing back our footprints to understand the present. HOW, A Colombian Journal for Teachers of English, 24(1), 10-26. https://doi.org/10.19183/how.24.1.348

Bastidas, J. A., \& Munoz, G. (2011). A diagnosis of English language teaching in public elementary schools in Pasto, Colombia. HOW, A Colombian Journal for Teachers of English, 18(1), 95-111.

Birch, B. (2009). The English Language Teacher in Global Civil Society. New York: Routledge. https://doi.org/10.4324/9780203878040

Bonilla, C. A., \& Tejada-Sanchez, I. (2016). Unanswered questions in Colombia's foreign language education policy. Profile, Issues in Teachers' Professional Development, 18(1), 185-201. https://doi.org/10.15446/profile.v18n1.51996 
Bonilla, S. X., \& Cruz-Arcila, F. (2014). Critical socio-cultural elements of the intercultural endeavour of English teaching in Colombian rural areas. Profile, Issues in Teachers' Professional Development, 16(2), 117-133. https://doi.org/10.15446/profile.v16n2.40423

Bowen, G. (2009). Document analysis as a qualitative research method, Qualitative Research Journal, 9(2), 27-40. https://doi.org/10.3316/QRJ0902027

Cárdenas, R. (2001). Teaching English in primary: Are you ready for it? HOW, A Colombian Journal for Teachers of English, 8, 1-9.

Cardenas, R., \& Chaves, O. (2013). English teaching in Cali: Teachers' proficiency level described. Lenguaje, 41(2), 325-352. https://doi.org/10.25100/lenguaje.v41i2.4971

Cardenas, R., \& Hernandez, F. (2012). Opportunity to teach and learn standards: Colombian teachers' perspectives. Profile, Issues in Teachers' Professional Development, 14(2), 77-94.

Collins English Dictionary. (2018). Curriculum. In The Collins English Dictionary. Retrieved from https://www.collinsdictionary.com/dictionary/english/curriculum

COLOMBIA. (2016). Pedagogical Principles and Guidelines. Suggested English Curriculum. Colombia Bilingüe. Bogotá: Ministerio de Educación Nacional.

Confrey, J. (2006). Comparing and contrasting the National Research Council report on evaluating curricular effectiveness with the What Works Clearinghouse approach. Educational Evaluation and Policy Analysis, 28(3), 195-213. https://doi.org/10.3102/01623737028003195

Correa, D., \& Usma, J. (2013). From a bureaucratic to a critical sociocultural model of policymaking in Colombia. HOW, A Colombian Journal for Teachers of English, 20(1), 226-242.

Correa, D., Usma, J., \& Montoya, J. C. (2014). El Programa Nacional de Bilingüismo: Un estudio exploratorio en el departamento de Antioquia, Colombia [National Bilingual Program: An exploratory study in the Department of Antioquia, Colombia]. Íkala, Revista de Lenguaje y Cultura, 19(1), 101-116.

Council of Europe. (2001). Common European Framework of Reference for Languages. Cambridge: CUP.

Creswell, J. W. (2003). Research design: Qualitative, quantitative, and mixed methods approaches (2nd ed.). Thousand Oaks, CA: Sage.

Fandiño-Parra, Y. J., Bermúdez-Jiménez, J. R., \& Lugo-Vásquez, V. E. (2012). The challenges facing the National Program for Bilingualism: Bilingual Colombia. Educación y Educadores, 15(3), 363-381. https://doi.org/10.5294/edu.2012.15.3.2

Gimeno Sacristán, J. (2005). La educación que aún es posible. Madrid: Morata.

Glass, G. V., \& Hopkins, K. D. (1984). Statistical methods in education and psychology. Englewood Cliffs, NJ: Prentice Hall.

Gonzalez, A. (2007). Professional development of efl teachers in Colombia: Between colonial and local practices. Íkala, Revista de Lenguaje y Cultura, 12(18), 309-332.

Guerrero, C. H. (2008). Bilingual Colombia: What does it mean to be bilingual within the framework of the National Plan of Bilingualism? Profile, Issues in Teachers' Professional Development, 10(1), 27-45.

Guerrero, C. H. (2010). The portrayal of efl teachers in official discourse: The perpetuation of disdain. Profile, Issues in Teachers' Professional Development, 12(2), 33-49.

Herazo, J., Jerez, S., \& Lorduy, D. (2012). Opportunity and incentive for becoming bilingual in Colombia: Implications for Programa Nacional de Bilingüismo. Íkala, revista de lenguaje y cultura, 17(2), 199-213.

Malagon-Plata, L. (2009). La pertinencia curricular: un estudio en tres programas universitarios Educación y Educadores, 12(1), 11-27.

Marulanda, L., \& Berdugo Torres, M. (2011). Implementación del programa de informática y bilingüismo en una institución educativa de Cali. Lenguaje, 33. https://doi.org/10.25100/lenguaje.v33i0.4826

Meyer JW (2006) World models, national curricula, and the centrality of the individual. In A. Benavot, \& C. Braslavsky (Eds.), School Knowledge in Comparative and Historical Perspective. Changing Curricula in Primary and Secondary Education. Hong Kong: Springer, Comparative Education Research Center. https://doi.org/10.1007/978-1-4020-5736-6_16

Ministerio de Educación Nacional. (1994). Ley General de Educación 115. Santafé de Bogotá: MEN. 
Ministerio de Educación Nacional. (2006). Formar en lenguas extranjeras: Inglés ;El reto! Bogotá, D.C.: Imprenta Nacional.

Miranda, N., \& Echeverry, A. (2010). Infrastructure and resources of private schools in Cali and the implementation of the Bilingual Colombia Program. HOW, A Colombian Journal for Teachers of English, 17(1), 11-30.

Miranda, N., \& Echeverry, A. (2011). La gestión escolar en la implementación del Programa Nacional de Bilingüismo en instituciones educativas privadas de Cali (Colombia) [School administration in the implementation of the Bilingual Colombia Program in private educational institutions in Cali (Colombia)]. Íkala, Revista de Lenguaje y Cultura, 16(29), 67-125.

Montoya-Vargas, J. (2013). Curriculum Studies in Colombia. ed. In W. F. Pinar (Ed.), International Handbook of Curriculum Research. Routledge Handbooks Online. https://doi.org/10.4324/9780203831694.ch11

Nassaji, H. (2015). Qualitative and descriptive research: Data types versus data analysis. Language Teaching Research, 19(2), 129-132. https://doi.org/10.1177/1362168815572747

Osorio, M. (2017). El currículo: Perspectivas para acercarnos a su comprensión. Zona Próxima, 26, 142-151.

Peláez, O., \& Usma, J. (2017). The Crucial Role of Educational Stakeholders in the Appropriation of Foreign Language Education Policies: A Case Study. Profile: Issues in Teachers' Professional Development, 19(2), 121-134. https://doi.org/10.15446/profile.v19n2.57215

Penuel, W. (2009). Is alignment enough? Investigating the effects of state policies and professional development on science curriculum implementation. Science Education, 93(4), 656-677. https://doi.org/10.1002/sce.20321

Quintero, A. H., \& Guerrero, C. H. (2013). "Of Being and not Being”: Colombian public elementary school teachers' oscillating identities. HOW, A Colombian Journal for Teachers of English, 20(1), 190-205.

Rennekamp, R., \& Nall, M. (2008). Using focus groups in program development and evaluation. UK Cooperative Extension Services. Retrieved from https://psd.ca.uky.edu/files/focus

Reyes, Y. (2015, February 2). Colombia, very well! El Tiempo. Retrieved from http://www.eltiempo.com/opinion/columnistas/colombia-very-well-yolanda-reyes-columnista-el-tiempo/15 181161

Rowley, J. (2012). Conducting research interviews. Management Research Review, 35(3), 260-271. https://doi.org/10.1108/01409171211210154

Ruiz, M., Montenegro, M., \& Meneses, A. (2010). Coherencia Curricular entre el marco curricular y el texto escolar y la práctica educativa básico: Contenido y habilidades de pensamiento científico. Seminario Internacional sobre textos escolares de Matemáticas, Física y Química. Santiago de Chile.

Sadler, M. (1900). How far can we learn anything of practical value from the study of foreign systems of education? In J. H. Higginson (Ed.), Selections from Michael Sadler (pp. 48-51). Liverpool.

Sánchez, A., \& Obando, G. (2008). Is Colombia ready for "bilingualism"? Profile, Issues in Teachers' Professional Development, 9(1), 181-195.

Sarmiento, P., Empresas, M. A., \& Tovar, M. C. (2007). El análisis documental en el diseño curricular: Un desafío para los docentes. Colombia Médica, 38(4).

Schoenfeld, Alan. H. (2016).100 Years of Curriculum History, Theory, and Research. Educational Researcher, 45(2), 105-111. https://doi.org/10.3102/0013189X16639025

Sivesind, K., Afsar, A., \& Bachmann, K. (2016). Transnational policy transfer over three curriculum reforms in Finland: The constructions of conditional and purposive programs (1994-2016). European Educational Research Journal, 15(3), 345-365. https://doi.org/10.1177/1474904116648175

Stabback, P. (2016). Qué Hace a un Currículo de Calidad. Reflexiones en progreso $N^{o} 2$ sobre Cuestiones fundamentales $y$ actuales del currículo $y$ el aprendizaje. Retrieved from http://unesdoc.unesco.org/images/0024/002439/243975s.pdf

United Nations Educational, Scientific and Cultural Organization. (1998). Conferencia mundial sobre educación superior. La contribución al desarrollo nacional y regional. París: Author.

Usma, J. (2009). Globalization and language and education reform in Colombia: A critical outlook. Íkala, Revista de Lenguaje y Cultura, 14(22), 19-42. 
Usma, J. (2015). From transnational language policy transfer to local appropriation: The case of the National Bilingual Program in Medellin, Colombia. Blue Mounds, US: Deep University Press.

Velazco, M. (2011). On becoming bilingual: are we doing the right thing? Classroom implications of the National Bilingualism Program. Perspectivas en educación, 3, 7-12.

Wolhuter, C. C., Van der Walt, H., Potgieter, F., \& Steyn, H. (2014). The Possible Broadening of the Conceptualisation of Philosophy as a Shaping Factor of Education Systems. Croatian Journal of Education, 16(2), 547-577.

\section{Notes}

Note 1 . This represents courses from year 6 th to year 13 th in the UK education system; and year 6 th to year 12 th in the US education system.

Note 2. This represents courses from Reception year to year 5th in the UK education system and Pre-K to year 5 th in the US education system.

Note 3. Institution created to train high school graduates to be teachers.

\section{Copyrights}

Copyright for this article is retained by the author(s), with first publication rights granted to the journal.

This is an open-access article distributed under the terms and conditions of the Creative Commons Attribution license (http://creativecommons.org/licenses/by/4.0/). 